Research, Society and Development, v. 9, n. 7, e777974711, 2020

(CC BY 4.0) | ISSN 2525-3409 | DOI: http://dx.doi.org/10.33448/rsd-v9i7.4711

Araújo DL \& Oliveira JL (2020). Identification and analysis of bacterial presence in diagnostic imaging equipment. Research, Society and Development, 9(7): 1-7, e777974711.

\title{
Identificação e análise de presença bacteriana em equipamentos de diagnóstico por imagem
}

Identification and analysis of bacterial presence in diagnostic imaging equipment Identificación y análisis de la presencia de bacterias en los equipos de diagnóstico por imágenes

Recebido: 19/05/2020 | Revisado: 22/05/2020 | Aceito: 26/05/2020 | Publicado: 12/06/2020

Daniel Lopes Araújo

ORCID: https://orcid.org/0000-0002-1625-0368

Centro Universitário de Patos, Brasil

E-mail: daniel124.d1718@gmail.com

Júlia Lacerda de Oliveira

ORCID: https://orcid.org/0000-0003-1042-3544

Universidade Federal de Campina Grande, Brasil

E-mail: julia.lacerdade@gmail.com

\section{Resumo}

O objetivo dessa pesquisa foi analisar a presença bacteriana em equipamentos de diagnóstico por imagem, que no dia-a-dia hospitalar são frequentemente usados para diagnóstico de doenças. Foram feitas coletas de amostras de três equipamentos de radiodagnóstico, por meio da técnica de $s w a b$, para semeio feito em laboratório e posterior identificação. De acordo com as análises feitas em laboratório foi comprovada a presença de alguns tipos de bactérias, que dependendo de como o sistema imunológico do paciente esteja, podem ser prejudiciais para o organismo humano, além de serem observadas colônias de leveduras e fungos em grande quantidade em alguns compartimentos dos aparelhos coletados, outros constituintes dos aparelhos coletados não foram possíveis identificar nenhum tipo de colônia de bactéria, fungo ou levedura. É visível a importância das análises bacterianas nos aparelhos de diagnóstico por imagem, já que os mesmos podem está abrigando perigosos tipos de bactérias ou fungos e isso pode acabar ocasionando em infecções em pacientes que fazem a utilização dos equipamentos em questão. 
Research, Society and Development, v. 9, n. 7, e777974711, 2020

(CC BY 4.0) | ISSN 2525-3409 | DOI: http://dx.doi.org/10.33448/rsd-v9i7.4711

Palavras-chave: Contaminação; Aparelhos de radiodiagnóstico; Sthapylococcus; Ambiente hospitalar.

\begin{abstract}
The objective of this research was to analyze the bacterial presence in diagnostic imaging equipment, which in day-to-day hospital life are often used for disease diagnosis. Samples were collected from three diagnostic equipment, using the swab technique, for laboratory sowing and subsequent identification. According to the laboratory analyses, the presence of some types of bacteria was proven, which depending on how the patient's immune system is, can be harmful to the human organism, besides yeast and fungus colonies in large quantities were observed in some compartments of the collected apparatuses, other constituents of the collected apparatuses were not possible to identify any type of bacteria, fungus or yeast colony. The importance of bacterial analyses in imaging diagnostic devices is visible, since they can harbor dangerous types of bacteria or fungi and this can end up causing infections in patients who use the equipment in question.
\end{abstract}

Keywords: Contamination; Radiodiagnostic devices; Sthapylococcus; Hospital environment.

\title{
Resumen
}

El objetivo de esta investigación era analizar la presencia de bacterias en los equipos de diagnóstico por imágenes, que en la vida diaria del hospital se utilizan a menudo para el diagnóstico de enfermedades. Se recogieron muestras de tres equipos de diagnóstico, utilizando la técnica del hisopo, para su siembra en el laboratorio y posterior identificación. Según los análisis de laboratorio, se comprobó la presencia de algunos tipos de bacterias que, según el sistema inmunológico del paciente, pueden ser perjudiciales para el organismo humano, además de que se observaron colonias de levaduras y hongos en grandes cantidades en algunos compartimentos de los aparatos recolectados, otros componentes de los aparatos recolectados no pudieron identificar ningún tipo de bacteria, hongo o colonia de levadura. La importancia de los análisis bacterianos en los dispositivos de diagnóstico por imágenes es visible, ya que pueden albergar tipos peligrosos de bacterias u hongos y esto puede terminar causando infecciones en los pacientes que utilizan el equipo en cuestión.

Palabras clave: Contaminación; Dispositivos de Radiodiagnóstico; Sthapylococcus; Entorno hospitalario. 


\section{Introduction}

When it comes to a hospital environment, it is known that several invasive and noninvasive procedures are performed, which when done without proper care can cause the risks of cross contamination to increase in that place, specifically when there are materials or equipment that are for collective use. Most of the time, these microorganisms are obtained through the transmission of contact from the hands of the professional and patient or even by the patient's own contact with the equipment or accessory (Nelson, 2016; Silva, 2019). It is well known that the hospital environment can have a great influence on this issue, where the Intensive Care Units (ICU) are more prone to bacterial infection because it is an environment of serious instability in the clinical picture of patients in need of more special care, correlating the idea of cleaning, disinfection, physical structure and amount of equipment (Santos, 2019; Castro, 2018).

The presence of these microorganisms on the surfaces of equipment and accessories in hospital environments often do not pose greater risks to the human body, but if there is some kind of immunodepression, these microorganisms may end up becoming pathogenic elements. In this way, objects that are widely used without proper hygiene and in the possession of many people can end up becoming sites of contamination (Ferreira, 2016; França, 2018).

Some microbiological studies in hospitals have proven the presence of a wide range of bacteria on their surfaces, which causes them to become vehicles of mass contamination. This makes investigating the presence of bacteria in radiodiagnostic equipment an important alternative for the scientific community.

\section{Methodology}

\subsection{Place of study}

The experiments were performed at the Laboratory of Basic Sciences (CCB) of the University Center of Patos (UNIFIP).

\subsection{Obtaining the samples}

The microbiological collection was performed in two radiodiagnostic institutions in a city of the interior of Paraíba, through the swab technique, materials were collected from a 
Research, Society and Development, v. 9, n. 7, e777974711, 2020

(CC BY 4.0) | ISSN 2525-3409 | DOI: http://dx.doi.org/10.33448/rsd-v9i7.4711

radiography device (examination table, collimator, stationary, command table and lead apron), a mammograph and a computerized tomography device (examination table, arm support, skull support and granty). After collection, the material was taken to the sowing of the plates and subsequent bacterial identification.

\subsection{Culture medium}

The culture medium used in this study was Agar blood, already dissolved in distilled water and placed in the petri dish.

\section{Results and Discussion}

In Table 1 it is possible to observe the exposed results of the analysis and bacterial identification on the plaques after 10 days.

Table 1 - Analysis of the X-ray device plates.

\begin{tabular}{lcl}
\cline { 2 - 2 } Device compartment & Bacteria type \\
\hline Examination table & Yeast Cologne \\
Control desk & $* *$ \\
Collimator & $* *$ \\
Bucky vertical & $* *$ & \\
Lead apron & Sthapylococcus & epidermidis \\
\hline
\end{tabular}

** No bacteria colony could be analysed. Source: Survey data (2019).

The identification of the constituent compartments of a conventional radiography apparatus was able to prove that, on the examination table, the place where the patient is placed for positioning (in case he cannot perform the procedure in orthostatic position) showed a considerable number of yeast colony, but it was not possible to prove any site of bacteria. On the control table, collimator and vertical bucky it was not possible to prove any type of existing microorganism. In the lead apron, responsible for the radiological protection of the patient and the professional, it was possible to identify colonies of Sthapylococcus epidermidis.

Some studies prove that Sthapylococcus epidermidis is a type of microorganism naturally found in human skin, but which can cause disease when the patient's immune system 
Research, Society and Development, v. 9, n. 7, e777974711, 2020

(CC BY 4.0) | ISSN 2525-3409 | DOI: http://dx.doi.org/10.33448/rsd-v9i7.4711

is weakened, it is an opportunistic pathogen, strongly associated with nosocomial infections (Pardos, 2018).

Table 2 shows the result of the only sample collected from a mammography device.

Table 2 - Analysis of the mammography device plates.

\begin{tabular}{ll}
\cline { 2 - 2 } Device compartment & Bacteria type \\
\hline Mammography & Staphylococcus aureus. \\
\hline
\end{tabular}

Source: Research data (2019).

Staphylococcus aureus is a bacterium commonly found in our body, such as the skin, mouth, nose and intestines. Once in our body, Staphylococcus aureus may not be restricted only to our skin. If it invades the bloodstream, it can reach any organ, triggering severe infections, sepsis and septic shock. One of the most feared infections, caused by Staphylococcus aureus, is endocarditis, in the heart, but other possible infections are pneumonia, pyelonephritis and osteomyelitis (Oliveira, 2018; De Avelar, 2019).

Table 3 - Analysis of the CT device boards.

\begin{tabular}{lc}
\cline { 2 - 2 } Device compartment & Bacteria type \\
\hline Examination table & Yeast Cologne \\
Arm rest & $* *$ \\
Skull support & Yeast colony \\
Gantry or arch & Yeast and fungal structures in large \\
& quantity \\
\hline
\end{tabular}

** No bacteria colony could be analysed. Source: Survey data (2019).

\section{Final Considerations}

Therefore, in view of all that has been analyzed it is important to know that the lack of hygienization of hospital equipment, especially those for collective use can be great allies for the creation of colonies of bacteria and fungi, also correlating with the importance of microbiological analysis of these and other equipment that can trigger an important step to avoid possible contamination. The results obtained through these studies can serve as an alert for the redoubled care with the issue of bacterial infections. 


\section{References}

Avelar J. G, Almeida B. M, Rocha JA \& Gismondi R. A (2019). Infecção na sala de emergência: agentes, fontes e medidas simples de prevenção e controle. Academus Revista Científica da Saúde, 4(3), 29-39.

Castro E. V. B \& Miguel N. A (2018, January). Contaminação por sthapylococcus aureus nos chassis radiográficos em hospital de ensino. In Colloquium Vitae (10(1).

Ferreira R. E. C, Neto J. R, Antas M. D. G. C, Sobrinho C. R. W \& Perez F. M. D. M. R (2016). Eficácia de três substâncias desinfetantes na prática da radiologia odontológica. Revista Brasileira de Odontologia, 73(1), 14.

França Â. M. O. S, Villaruz A, Cerca N \& Otto M (2018, August). Staphylococcus epidermidis wall teichoic acid confers tolerance to antibiotics and immune defense in human blood. In ISSSI 2018-International Symposium on Staphylococci and Staphylococcal Infections (No. P068, p. 166).

Pardos de la Gandara, M, Borges V, Chung M, Milheiriço C, Gomes J. P, Lencastre H \& Tomasz A (2018). Genetic determinants of high-level oxacillin resistance in methicillinresistant Staphylococcus aureus. Antimicrobial Agents and Chemotherapy, 62(6), pii-e00206.

Nelson J, Bivens A, Shinn A, Wanzer L \& Kasper C. Microbial Flora on Operating Room Telephones, Association of operating room nurses. AORN J. 2016;83(3):607-26. DOI: https://doi.org/10.1016/S0001-2092(06)60190-7.

Oliveira G. S (2018). Estudo teórico do uso de radiação ultravioleta para controle de microorganismos em água.

Silva B. R. D \& Lopes M. P (2019). Avaliação da contaminação de luvas de procedimento antes do atendimento odontológico. 
Research, Society and Development, v. 9, n. 7, e777974711, 2020

(CC BY 4.0) | ISSN 2525-3409 | DOI: http://dx.doi.org/10.33448/rsd-v9i7.4711

Santos Moura A, Souza G. M, Alves M. G, Brito, MV, Ladeira L. D. M. C, Mendonça V. F ... \& Carvalho M. T. M (2019). • Resistência bacteriana associada aos casos de infecção hospitalar na Santa Casa de Misericórdia de Passos (MG): estudo de caso. Ciência ET Praxis (Qualis B3-2017-2018), 11(21), 95-106.

\section{Percentage of contribution of each author in the manuscript}

Daniel Lopes Araújo - 50\%

Júlia Lacerda de Oliveira - 50\% 